\title{
Hypocretin/Orexin Receptor Pharmacology and Sleep Phases
}

\author{
Yu Sun Ryan K. Tisdale Thomas S. Kilduff \\ Center for Neuroscience, Biosciences Division, SRI International, Menlo Park, CA, USA
}

\begin{abstract}
The hypocretins/orexins are two excitatory neuropeptides, alternately called HCRT1 or orexin-A and $H C R T 2$ or orexin- $B$, that are the endogenous ligands for two $G$-protein-coupled receptors, $H C R T R 1 / O X_{1} R$ and HCRTR2/OX ${ }_{2} R$. Shortly after the discovery of this system, degeneration of hypocretin/orexin-producing neurons was implicated in the etiology of the sleep disorder narcolepsy. The involvement of this system in a disorder characterized by the loss of control over arousal state boundaries also suggested its role as a critical component of endogenous sleep-wake regulatory circuitry. The broad projections of the hypocretin/orexin-producing neurons, along with differential expression of the two receptors in the projection fields of these neurons, suggest distinct roles for these receptors. While HCRTR1/OX $R$ is associated with regulation of motivation, reward, and autonomic functions, $H C R T R 2 / O X_{2} R$ is strongly linked to sleep-wake control. The association of hypocretin/orexin with these physiological processes has led to intense interest in the therapeutic potential of compounds targeting these receptors. Agonists and antagonists for the hypocretin/orexin receptors have shown potential for the treatment of disorders of excessive daytime somnolence and nocturnal hyperarousal, respectively, with the first antagonists approved by the US Food and Drug Administration (FDA) in 2014 and 2019 for the treatment of insomnia. These and related compounds have also been useful tools to advance hypocretin/orexin neurobiology.

(C) 2021 The Author(s)

Published by S. Karger AG, Basel
\end{abstract}

\section{Hypocretins/Orexins and Their Receptors}

\section{Discovery}

In 1998, two research groups independently identified a pair of structurally similar excitatory neuropeptides $[1,2]$. These neuropeptides were determined to be the endogenous ligands for two orphan G-protein-coupled receptors (GPCRs) and were named the "hypo- 
cretins" by one group [1] for their restricted localization to the hypothalamus and their structural similarity to secretin, and the "orexins" by the other group [2] after the Greek word orexis meaning appetite, based on the increased food intake associated with intracerebroventricular (ICV) administration of the neuropeptides in rats. Shortly after the discovery of the hypocretins/orexins, dysfunction of this neurotransmitter system was implicated in animal models of the sleep disorder narcolepsy $[3,4]$, which subsequently led to the discovery of loss of these neurons as the etiology underlying human narcolepsy $[5,6]$. The link between this neuropeptide system and a disorder of excessive sleepiness also suggested a role for this system in the regulation of arousal states [7, 8]. The implication of this system as the cause of narcolepsy and in sleep regulation led to immediate interest in the potential of agonists and antagonists targeting the hypocretin/orexin receptors for the treatment of sleep disorders.

\section{Neuropeptides and Receptor Pharmacology}

The two neuropeptides, alternately called hypocretin 1 (HCRT1) or orexin-A and hypocretin 2 (HCRT2) or orexin-B, are cleaved from the prepro-orexin precursor. HCRT1/ orexin-A is a 2,562-Da polypeptide, 33 amino acids in length, whereas HCRT2/orexin-B is a linear 2,397-Da polypeptide, 28 amino acids in length [2]. Both peptides share a structurally similar amidated C-terminal, which is crucial for both the binding of the peptides and activation of the cognate receptors, whereas the $\mathrm{N}$-terminal peptide sequence is more variable between HCRT1/orexin-A and HCRT2/orexin-B [2]. Hypocretin/orexin receptor $1\left(\mathrm{HCRTR} 1 / \mathrm{OX}_{1} \mathrm{R}\right)$ and receptor $2\left(\mathrm{HCRTR} 2 / \mathrm{OX}_{2} \mathrm{R}\right)$ share $64 \%$ sequence similarity in humans [2]. While HCRTR1/OX $\mathrm{O}_{1}$ shows a selective binding affinity for HCRT1/orexin-A, HCRTR2/OX ${ }_{2} \mathrm{R}$ has an equal affinity for both neuropeptides [2]. Despite the similarities of both hypocretin/orexin neuropeptide and receptor subtypes, the two receptors are differentially expressed within the brain [9], suggesting they have distinct physiological functions (Fig. 1).

GPCRs such as HCRTR1/OX $\mathrm{R}$ and HCRTR2/OX $\mathrm{OX}_{2} \mathrm{R}$ are composed of seven transmembrane helices. The C-terminal portion of helices 2-4 of HCRTR1/OX $\mathrm{R}$ and HCRTR2/OX ${ }_{2} \mathrm{R}$ confer differential selectivity of the two receptors [10], although the specific differences in the structure of HCRTR1/OX $\mathrm{R}$ and HCRTR2/OX 2 R that result in receptor specificity are subtle. Both receptors also contain an N-terminal amphipathic a-helix that mediates the binding of the orexin neuropeptides [11]. A substitution of threonine for alanine at the 3.33 position and threonine for serine at the 2.61 position within the binding pocket of human HCRTR2/OX ${ }_{2} \mathrm{R}$ causes a $5 \%$ decrease in the volume of the pocket compared with $\mathrm{HCRTR} 1 / \mathrm{OX}_{1} \mathrm{R}$, a feature that may mediate receptor selectivity and, furthermore, could be exploited to confer specificity when designing molecules selective for each of the two receptors [11].

\section{Evolutionary Insights}

Hypocretin/orexin-containing neurons have been identified in the hypothalamic region of a variety of vertebrates, and the components of the orexin system are highly conserved 




Fig. 1. Hypocretin/orexin-containing neurons and their projections, receptor distributions, and downstream behavioral outcomes. Hypocretin/orexin-producing neurons are located in the hypothalamus (Hy) and project to diverse brain regions differentially expressing hypocretin/orexin receptors 1 and 2 $\left(\mathrm{OX}_{1} \mathrm{R}\right.$ and $\mathrm{OX}_{2} \mathrm{R}$; receptor expression is indicated by the background color of each brain region), including the cerebral cortex, cingulate cortex, bed nucleus of the stria terminalis (BNST), nucleus accumbens (NAc), tuberomammillary nucleus (TMN), dorsal raphe (DR), locus coeruleus (LC), paraventricular thalamus (PVT), ventrolateral periaqueductal gray (vIPAG), the dorsal deep mesencephalic nucleus (dDPMe), pedunculopontine and laterodorsal tegmental nuclei (PPT and LDT), substantia nigra (SN), ventral tegmental area (VTA), central area of the amygdala (CeA), and the paraventricular nucleus (PVN). Through these projections, hypocretin/orexin-containing neurons are able to elicit diverse behavioral outputs.

across vertebrates [12]. Two genes encoding peptides with structural similarity to HCRT1/ orexin-A have been identified in Amphioxus, an extant member of the basal chordate subphylum Cephalochordata, that is often studied to provide insight into early vertebrate evolution [13]. The orexin-A-like peptide is expressed in the neural chord of Amphioxus. Since the neural chord is believed to be a precursor to the vertebrate brain, the hypocretin/ orexin system might have already been present in some form prior to the diversification of the vertebrates. The presence of a conserved hypocretin/orexin neuronal system among widespread phylogenetic groups indicates strong selective pressure to maintain a vital function subserved by this network.

\section{Hypocretin/Orexin Receptor Antagonists (aka SORAs and DORAs)}

Hypocretin/orexin-producing neurons project to brain regions involved in regulating reward, learning, memory, emotion, attention, and arousal states [14]. The innervation of brain structures involved in the regulation of these various functions has made the development of hypocretin/orexin receptor antagonists an active area of investigation for the treatment of addiction, sleep disorders, obesity, mood, anxiety, and panic disorders. There are two main classes of hypocretin/orexin receptor antagonists, those selective for a spe- 
Table 1. Effects of hypocretin/orexin receptor agonists and antagonists on sleep/wake in preclinical studies

\begin{tabular}{|c|c|c|c|c|c|c|}
\hline \multirow[t]{2}{*}{ Drugs } & \multirow[t]{2}{*}{ Species/strain } & \multicolumn{4}{|c|}{ Arousal state parameters } & \multirow[t]{2}{*}{ Ref. } \\
\hline & & $\begin{array}{l}\text { wakeful- } \\
\text { ness }\end{array}$ & $\begin{array}{l}\text { NREM } \\
\text { sleep }\end{array}$ & $\begin{array}{l}\text { REM } \\
\text { sleep }\end{array}$ & cataplexy & \\
\hline \multicolumn{7}{|l|}{ Hypocretin/orexin receptor agonists } \\
\hline $\begin{array}{l}\text { HCRT1/orexin- } A \text { (dual } O X_{1} R / \\
\mathrm{OX}_{2} \mathrm{R} \text { agonist) }\end{array}$ & WT, $O X_{1} R \mathrm{KO}, O X_{2} R \mathrm{KO}$ and $O X_{1} R ; O X_{2} R$ DKO mice & $\uparrow$ & $\downarrow$ & $\downarrow$ & $\mathrm{N} / \mathrm{A}$ & {$[42]$} \\
\hline TAK925 (HCRTR2/OX 2 R agonist) & $\mathrm{C} 57 \mathrm{BL} / 6 \mathrm{~J}, \mathrm{OX}_{2} R \mathrm{KO}$ and orexin/ataxin-3 mice & $\uparrow$ & $\downarrow$ & $\downarrow$ & $\downarrow$ & {$[63,65]$} \\
\hline TAK994 (HCRTR2/OX 2 R agonist) & Orexin/ataxin-3 mice & $\uparrow$ & $\downarrow$ & $\downarrow$ & $\mathrm{N} / \mathrm{R}$ & {$[69]$} \\
\hline YNT185 (HCRTR2/OX 2 R agonist) & $\begin{array}{l}\mathrm{C} 57 \mathrm{BL} / 6 \mathrm{~J}, \text { prepro-OXKO, and } O X_{1} R ; O X_{2} R \mathrm{DKO} \text { and } \\
\text { orexin/ataxin-3 mice }\end{array}$ & $\uparrow$ & $\downarrow$ & $\begin{array}{l}\text { ICV: NC; } \\
\text { IP: } \downarrow\end{array}$ & $\downarrow$ & {$[62]$} \\
\hline \multicolumn{7}{|c|}{ Dual hypocretin/orexin receptor antagonists (DORAs) } \\
\hline \multirow[t]{5}{*}{ Almorexant (ACT-078573) } & Wistar rats & $\downarrow$ & $\uparrow$ & $\uparrow$ & $\mathrm{N} / \mathrm{A}$ & {$[15]$} \\
\hline & Sprague-Dawley rats & $\downarrow$ & $\uparrow$ & $\uparrow$ & $\mathrm{N} / \mathrm{A}$ & {$[74]$} \\
\hline & Sprague-Dawley rats & $\downarrow$ & $\uparrow$ & $\uparrow$ & $\mathrm{N} / \mathrm{A}$ & {$[48]$} \\
\hline & Orexin/ataxin-3 and WT littermate mice & $\downarrow$ & $\uparrow$ & $\uparrow$ & $\uparrow$ & {$[86]$} \\
\hline & $\begin{array}{l}\text { C57BL/6NCrlCrlj mice, F344/DuCrICrlj rats, } \\
\text { Sprague-Dawley rats, orexin/ataxin-3 mice }\end{array}$ & $\downarrow$ & $\uparrow$ & $\uparrow$ & $\mathrm{N} / \mathrm{R}$ & [87] \\
\hline Daridorexant (ACT-541468) & Wistar rats & $\downarrow$ & $\uparrow$ & $\uparrow$ & $\mathrm{N} / \mathrm{R}$ & {$[29]$} \\
\hline \multirow[t]{2}{*}{ Lemborexant (E2006) } & $\begin{array}{l}\text { C57BL/6NCrlCrlj mice, F344/DuCrlCrlj rats, } \\
\text { Sprague-Dawley rats, orexin/ataxin-3 mice }\end{array}$ & $\downarrow$ & $\uparrow$ & $\uparrow$ & $\mathrm{N} / \mathrm{R}$ & {$[87]$} \\
\hline & C57BL/6J and prepro-OXKO mice & $\downarrow$ & $\uparrow$ & $\uparrow$ & $\uparrow$ & {$[88]$} \\
\hline Suvorexant (MK-4305) & Sprague-Dawley rats & $\downarrow$ & $\uparrow$ & $\uparrow$ & $\mathrm{N} / \mathrm{A}$ & {$[89]$} \\
\hline
\end{tabular}

HCRTR1/OX ${ }_{1}$ antagonists (1-SORAs)

\begin{tabular}{|c|c|c|c|c|c|c|}
\hline ACT-335827 & Sprague-Dawley rats & $\mathrm{NC}$ & $\mathrm{NC}$ & NC & $\mathrm{N} / \mathrm{A}$ & {$[50]$} \\
\hline \multirow[t]{3}{*}{ Compound 56} & Sprague-Dawley rats & $\mathrm{NC}$ & $\mathrm{NC}$ & $\mathrm{NC}$ & $\mathrm{N} / \mathrm{A}$ & [90] \\
\hline & OX WT mice & $\mathrm{N} / \mathrm{R}$ & $\mathrm{NC}$ & $\mathrm{NC}$ & $\mathrm{N} / \mathrm{A}$ & [90] \\
\hline & $\mathrm{OX}_{2} \mathrm{R} \mathrm{KO}$ mice & $\mathrm{N} / \mathrm{R}$ & $\mathrm{NC}$ & $\uparrow$ & $\mathrm{N} / \mathrm{R}$ & [90] \\
\hline GSK-1059865 & Sprague-Dawley rats & $\mathrm{NC}$ & $\mathrm{NC}$ & $\mathrm{NC}$ & $\mathrm{N} / \mathrm{A}$ & [91] \\
\hline \multirow[t]{3}{*}{ JNJ-54717793 } & Sprague-Dawley rats & $\mathrm{N} / \mathrm{R}$ & $\mathrm{NC}$ & $\mathrm{NC}$ & $\mathrm{N} / \mathrm{A}$ & [38] \\
\hline & OX WT mice & $\mathrm{N} / \mathrm{R}$ & $\mathrm{NC}$ & NC & $\mathrm{N} / \mathrm{A}$ & [38] \\
\hline & $\mathrm{OX}_{2} \mathrm{R} \mathrm{KO}$ mice & $\mathrm{N} / \mathrm{R}$ & NC & $\uparrow$ & $N / R$ & [38] \\
\hline \multirow[t]{3}{*}{ JNJ-61393215 } & Sprague-Dawley rats & $\mathrm{NC}$ & $\mathrm{NC}$ & $\mathrm{NC}$ & $\mathrm{N} / \mathrm{A}$ & [55] \\
\hline & OX WT mice & $\mathrm{N} / \mathrm{R}$ & $\mathrm{NC}$ & $\mathrm{NC}$ & $\mathrm{N} / \mathrm{A}$ & [55] \\
\hline & $\mathrm{OX}_{2} \mathrm{R} \mathrm{KO}$ mice & $\mathrm{N} / \mathrm{R}$ & $\mathrm{NC}$ & $\uparrow$ & $\mathrm{N} / \mathrm{R}$ & {$[55]$} \\
\hline \multirow[t]{2}{*}{ SB-334867 } & Sprague-Dawley rats & $\downarrow$ & $\uparrow$ & $\uparrow$ & $\mathrm{N} / \mathrm{A}$ & [48] \\
\hline & Hooded Lister rats & $\mathrm{NC}$ & $\mathrm{NC}$ & $\mathrm{NC}$ & $\mathrm{N} / \mathrm{A}$ & [49] \\
\hline
\end{tabular}


Table 1 (continued)

\begin{tabular}{|c|c|c|c|c|c|c|}
\hline \multirow[t]{2}{*}{ Drugs } & \multirow[t]{2}{*}{ Species/strain } & \multicolumn{4}{|c|}{ Arousal state parameters } & \multirow[t]{2}{*}{ Ref. } \\
\hline & & $\begin{array}{l}\text { wakeful- } \\
\text { ness }\end{array}$ & $\begin{array}{l}\text { NREM } \\
\text { sleep }\end{array}$ & $\begin{array}{l}\text { REM } \\
\text { sleep }\end{array}$ & cataplexy & \\
\hline \multicolumn{7}{|c|}{ HCRTR2/OX ${ }_{2} R$ antagonists (2-SORAs) } \\
\hline EMPA & Sprague-Dawley rats & $\begin{array}{l}\mathrm{NC} \\
\text { (most } \\
\text { doses) }\end{array}$ & $\begin{array}{l}\uparrow \text { (high } \\
\text { dose } \\
\text { only) }\end{array}$ & NC & $\mathrm{N} / \mathrm{A}$ & {$[48]$} \\
\hline JNJ-10397049 & Sprague-Dawley rats & $\mathrm{N} / \mathrm{R}$ & $\uparrow$ & NC & $\mathrm{N} / \mathrm{A}$ & [74] \\
\hline MK-1064 & $\begin{array}{l}\text { WT and HCRTR1; HCRTR2 DKO mice, } \\
\text { Sprague-Dawley rats, and beagles }\end{array}$ & $\downarrow$ & $\uparrow$ & $\begin{array}{l}\mathrm{NC} \text { in } \\
\text { mice; } \\
\uparrow \text { in rat }\end{array}$ & $\begin{array}{l}\text { N/R in } \\
\text { DKO mice; } \\
\text { NC in } \\
\text { beagles }\end{array}$ & {$[84]$} \\
\hline MK-3697 & Mouse, rat, and dog & $\downarrow$ & $\uparrow$ & $\uparrow$ & N/A & {$[75]$} \\
\hline MK-8133 & Mouse, rat, and dog & $\downarrow$ & $\uparrow$ & $\begin{array}{l}\uparrow \text { in rat } \\
\text { only }\end{array}$ & $\mathrm{N} / \mathrm{A}$ & [92] \\
\hline $\begin{array}{l}\text { Seltorexant (JNJ-42847922/ } \\
\text { MIN-202) }\end{array}$ & Sprague-Dawley rats, $\mathrm{C} 7 \mathrm{BL} 6$ and $\mathrm{OX}_{2} \mathrm{R} \mathrm{KO}$ mice & $N / R$ & $\uparrow$ & NC & $\mathrm{N} / \mathrm{R}$ & [73] \\
\hline
\end{tabular}

DKO, double knockout; HCRT, hypocretin; HCRTR, hypocretin receptor; ICV, intracerebroventricular; IP, intraperitoneal; KO, knockout; N/A, not applicable; NC, no change; N/R, not reported; NREM, non-rapid eye movement; REM, rapid eye movement; WT, wild-type.

cific hypocretin/orexin receptor known as selective orexin receptor antagonists (SORAs), i.e. selective antagonists for receptor 1 (1-SORAs) or receptor 2 (2-SORAs), and those with binding affinity for both receptors, the dual orexin receptor antagonists (DORAs). Most of the current hypocretin/orexin receptor-directed drugs have focused on antagonizing the role of this system in promoting and maintaining wakefulness for the treatment of insomnia and other disorders of nocturnal sleep disruption.

Hypothalamic hypocretin/orexin-producing neurons promote wakefulness through release of these excitatory peptides and glutamate at synapses in multiple brain regions involved in the regulation of arousal states (Fig. 1). Conversely, hypocretin/orexin antagonists promote sleep through the inhibition of the waking drive mediated by the hypocretin/orexin system; consequently, these drugs are used for the treatment of insomnia and disorders of impaired nocturnal sleep. Two DORAs, suvorexant and lemborexant, have been approved by the US Food and Drug Administration (FDA) to date, and a number are in clinical trials. Although almorexant was the first DORA shown to reduce sleep latency in several species (Tables 1 and 2) and to decrease wake after sleep onset (WASO) in humans $[15,16]$, clinical development was curtailed due to its hepatoxicity.

In 2014, the DORA suvorexant (formerly, MK-4305) was the first hypocretin/orexin antagonist approved by the FDA for the treatment of chronic insomnia. Suvorexant binds to HCRTR1/OX $\mathrm{O}_{1}$ and HCRTR2/OX 2 R with nanomolar affinity, thereby inhibiting hypocretin/orexin receptor signaling through the competitive occupation of receptor binding sites [17]. The binding of suvorexant to HCRTR2/OX $\mathrm{O}_{2} \mathrm{R}$ also stabilizes a network of extracellular salt bridges and blocks transmembrane helix motions needed for receptor activation [18]. This inhibition of orexin receptor signaling promotes sleep by attenuating the 
Table 2. Effects of hypocretin/orexin receptor antagonists on sleep/wake parameters in clinical studies

\begin{tabular}{|c|c|c|c|c|c|c|c|c|c|c|c|}
\hline Drugs & Subject population & WASO & TST & SOL & SWSL & $\begin{array}{l}\text { NREM/ } \\
\text { SWS }\end{array}$ & REM & REML & LPS & SE & Ref. \\
\hline \multicolumn{12}{|l|}{ DORAs } \\
\hline \multirow[t]{3}{*}{ Almorexant } & Healthy control samples & NC & NC & $\mathrm{N} / \mathrm{R}$ & $\downarrow$ & NC & $\uparrow$ & $\downarrow$ & $\downarrow$ & $\mathrm{NC}$ & {$[15,93]$} \\
\hline & $\begin{array}{l}\text { Adult chronic insomnia samples } \\
(\geq 100 \mathrm{mg})\end{array}$ & $\downarrow$ & $\uparrow$ & $\downarrow$ & $\downarrow$ & $\uparrow$ & $\uparrow$ & $\downarrow$ & $\downarrow$ & $\uparrow$ & [93] \\
\hline & Elderly patients with primary insomnia & $\downarrow$ & $\uparrow$ & $\mathrm{N} / \mathrm{R}$ & NC & NC & $\uparrow$ & $\downarrow$ & $\downarrow$ & $\mathrm{N} / \mathrm{R}$ & {$[94]$} \\
\hline Daridorexant & $\begin{array}{l}\text { Insomnia disorder } \\
\text { Elderly with Insomnia }\end{array}$ & $\downarrow$ & $\uparrow$ & $\begin{array}{l}N / R \\
N / R\end{array}$ & $\begin{array}{l}N / R \\
N / R\end{array}$ & $\begin{array}{l}N / R \\
N / R\end{array}$ & $\begin{array}{l}N / R \\
N / R\end{array}$ & $\begin{array}{l}N / R \\
N / R\end{array}$ & $\downarrow$ & $\begin{array}{l}N / R \\
N / R\end{array}$ & $\begin{array}{l}{[27]} \\
{[28]}\end{array}$ \\
\hline Filorexant & Clinical insomnia samples & $\downarrow$ & $\uparrow$ & $\mathrm{N} / \mathrm{R}$ & $N / R$ & NC & $\uparrow$ & $\downarrow$ & $\downarrow$ & $\uparrow$ & {$[31]$} \\
\hline Lemborexant & Clinical insomnia samples & $\downarrow$ & $N / R$ & $\mathrm{~N} / \mathrm{R}$ & $\mathrm{N} / \mathrm{R}$ & $N / R$ & NC & $N / R$ & $\downarrow$ & $\uparrow$ & {$[23,24]$} \\
\hline \multirow[t]{3}{*}{ SB-649868 } & Healthy control samples & $\downarrow$ & $\uparrow$ & $\mathrm{N} / \mathrm{R}$ & $N / R$ & $\downarrow$ & $\uparrow$ & $\downarrow$ & $\downarrow$ & $\mathrm{N} / \mathrm{R}$ & {$[95]$} \\
\hline & $\begin{array}{l}\text { Healthy control sample in situational } \\
\text { insomnia }\end{array}$ & $\downarrow$ & $\uparrow$ & $\mathrm{N} / \mathrm{R}$ & $\mathrm{N} / \mathrm{R}$ & $\uparrow$ & $\uparrow$ & $\downarrow$ & $\downarrow$ & $\uparrow$ & {$[96]$} \\
\hline & Clinical insomnia samples & $\downarrow$ & $\uparrow$ & $\mathrm{N} / \mathrm{R}$ & $\downarrow$ & $\downarrow$ & $\uparrow$ & $\downarrow$ & $\downarrow$ & $\uparrow$ & [97] \\
\hline \multirow[t]{4}{*}{ Suvorexant } & Healthy control samples & $\downarrow$ & $\uparrow$ & $\mathrm{N} / \mathrm{R}$ & $\mathrm{N} / \mathrm{R}$ & $\uparrow$ & $\uparrow$ & $\mathrm{N} / \mathrm{R}$ & $\downarrow$ & $\uparrow$ & {$[21,98]$} \\
\hline & Clinical insomnia samples & $\downarrow$ & $\uparrow$ & $\downarrow$ & $\mathrm{N} / \mathrm{R}$ & $\uparrow$ & $\uparrow$ & $\downarrow$ & $\downarrow$ & $\uparrow$ & {$[82,99]$} \\
\hline & Insomnia with obstructive sleep apnea & $\downarrow$ & $\uparrow$ & $\mathrm{N} / \mathrm{R}$ & $\mathrm{N} / \mathrm{R}$ & $\uparrow$ & $\uparrow$ & $N / R$ & NC & $\uparrow$ & {$[100]$} \\
\hline & Chronic obstructive pulmonary disorder & $\downarrow$ & $\uparrow$ & $\mathrm{N} / \mathrm{R}$ & $\mathrm{N} / \mathrm{R}$ & $\uparrow$ & $\uparrow$ & $N / R$ & $\downarrow$ & $\uparrow$ & [101] \\
\hline \multicolumn{12}{|l|}{ 2-SORAs } \\
\hline \multirow[t]{4}{*}{ Seltorexant } & Healthy control samples & $\mathrm{N} / \mathrm{R}$ & $\begin{array}{l}\uparrow(\text { som- } \\
\text { nolence) }\end{array}$ & $N / R$ & $N / R$ & $\mathrm{~N} / \mathrm{R}$ & $\mathrm{N} / \mathrm{R}$ & $\mathrm{N} / \mathrm{R}$ & $\mathrm{N} / \mathrm{R}$ & $\mathrm{N} / \mathrm{R}$ & {$[102]$} \\
\hline & $\begin{array}{l}\text { Insomnia without psychiatric } \\
\text { comorbidity }\end{array}$ & $\downarrow$ & $\uparrow$ & $\downarrow$ & $\mathrm{N} / \mathrm{R}$ & $\mathrm{NC}(\mathrm{N} 3)$ & $\uparrow$ & $\downarrow$ & $\downarrow$ & $\uparrow$ & {$[25]$} \\
\hline & Major depressive disorder (MDD) & NC & NC & $\mathrm{N} / \mathrm{R}$ & $\mathrm{N} / \mathrm{R}$ & $\mathrm{N} / \mathrm{R}$ & $\mathrm{N} / \mathrm{R}$ & $\mathrm{N} / \mathrm{R}$ & $\downarrow$ & $\uparrow$ & {$[78]$} \\
\hline & MDD with persistent insomnia & NC & $\uparrow$ & $\mathrm{N} / \mathrm{R}$ & $\mathrm{N} / \mathrm{R}$ & $\begin{array}{l}\mathrm{NC}(\mathrm{N} 2 \\
\& \mathrm{~N} 3)\end{array}$ & NC & $N / R$ & $\downarrow$ & $\uparrow$ & {$[76]$} \\
\hline MK-1064 & Healthy control samples & $\downarrow$ & $\uparrow$ & $\mathrm{N} / \mathrm{R}$ & $\mathrm{N} / \mathrm{R}$ & $\uparrow$ & $\uparrow$ & $\downarrow$ & $\downarrow$ & $\uparrow$ & {$[84]$} \\
\hline
\end{tabular}

wake-promoting effect of the hypocretin/orexin system, resulting in an increase in the number of transitions to non-rapid eye movement (NREM) and REM sleep in laboratory rodents whose sleep is polyphasic (Table 1) [19]. Like almorexant, suvorexant reduces the latency to persistent sleep (LPS), decreases WASO, and increases total sleep time (TST; Table 2) in humans [20-22]. The DORA lemborexant [23, 24] was approved by the FDA for insomnia in 2019 (Table 2). Several other drugs with sleep-promoting effects, for example, the 2-SORA seltorexant $[25,26]$ are in clinical development (Table 2) and a New Drug Application for the DORA daridorexant, which showed significant improvements in sleep as well as daytime functioning in clinical trials [27-29], was submitted to the FDA in January 2021. Development of the DORA filorexant (MK-6096) [30, 31] was abandoned by Merck. 


\section{HCRTR1/OX ${ }_{1} R$}

\section{Putative Roles}

HCRTR1/OX $\mathrm{R}_{1}$ knockout (KO) mice exhibit mild sleep disruption, increased anxiety, depression-like behavior, and startle response, as well as decreased locomotory activity, prepulse inhibition, and social interaction, suggesting a diverse role for HCRTR $1 / \mathrm{OX}_{1} \mathrm{R}$ [32]. HCRTR1/OX $\mathrm{O}_{1}$ signaling has also been implicated in drug, alcohol, and food-seeking behavior through modulation of motivational activation (Fig. 1) [33]. Studies utilizing HCRTR1/OX $\mathrm{O}_{1} \mathrm{R}$ antagonists have described anxiolytic, anti-stress, and anti-rewarding properties, further implying a role for $\mathrm{HCRTR}_{1} / \mathrm{OX}_{1} \mathrm{R}$ signaling in these processes [3438]. Although $H C R T R 2 / O X_{2} R$ and dual $\mathrm{OX}_{1} R / \mathrm{OX}_{2} \mathrm{R}$ null mutant (i.e., $\mathrm{KO}$ ) mice both exhibit a sleep and behavioral phenotype consistent with narcolepsy, the phenotype is more pronounced in the dual receptor KO mice [39-41], suggesting synergistic interaction between the two hypocretin/orexin receptor subtypes in sleep-wake control.

\section{Selective HCRTR1/OX $\mathrm{R}$ Agonists}

To our knowledge, no selective HCRTR1/OX $\mathrm{R}$ agonists have been identified to date. ICV administration of HCRT1/orexin-A, the endogenous ligand for both HCRTR1/OX $\mathrm{O}_{1}$ $\left(\mathrm{IC}_{50}=20 \mathrm{nM}\right)$ and HCRTR2/OX $2 \mathrm{R}\left(\mathrm{IC}_{50}=38 \mathrm{nM}\right)$ [2], results in increased wake and decreased NREM and REM sleep compared to control mice receiving vehicle injections [42]. When administered intranasally in humans, HCRT1/orexin-A has a REM-stabilizing effect but, given the affinity of orexin-A for both $\mathrm{HCRTR}_{1} / \mathrm{OX}_{1} \mathrm{R}$ and $\mathrm{HCRTR} 2 / \mathrm{OX}_{2} \mathrm{R}$, the effects of administration of this peptide could be mediated by either or both receptors [43, 44]. While sleep regulation is more clearly associated with $\mathrm{HCRTR} 2 / \mathrm{OX}_{2} \mathrm{R}$ agonism, HCRT1/orexin-A administration also triggers drug-seeking behavior, alterations in autonomic physiology, increased food intake, and has antidepressant effects which are likely regulated by HCRTR1/OX $\mathrm{R}$ activation [34, 45-47]. These results suggest some of the physiological effects that might be expected from $\mathrm{HCRTR}_{1} / \mathrm{OX}_{1} \mathrm{R}$ agonists.

\section{Selective HCRTR1/OX $\mathrm{O}_{1}$ Antagonists (1-SORAs)}

SB-334867 was the first 1-SORA to be described [35] and has been shown to reduce reward-seeking behavior associated with drug addiction and the consumption of high-fat foods [34-37]. SB-334867 also decreases wake and increases both NREM and REM sleep in rats, an effect that is consistent with, but is modest in comparison to, that seen following the administration of DORAs (Table 1) [48]. Furthermore, SB-334867 reverses the sleep modulatory effects of HCRT1/orexin-A administration [49]. The sleep modulatory effects of 1-SORAs have not been consistent between studies and compounds; nevertheless, these results suggest a modest role for $\mathrm{HCRTR} 1 / \mathrm{OX}_{1} \mathrm{R}$ signaling in sleep regulation that will require further study to fully elucidate [48-50].

Administration of another 1-SORA, JNJ-54717793, reduced panic-induced behaviors and cardiovascular responses in preclinical models of panic and anxiety without affecting baseline activity patterns, suggesting that $\mathrm{HCRTR} 1 / \mathrm{OX}_{1} \mathrm{R}$ antagonists might represent a 
novel treatment for anxiety conditions [38]. Several other 1-SORAs have been identified; however, their behavioral effects and therapeutic utility have yet to be evaluated [51-53]. While DORAs have also shown potential in the treatment of addiction and certain neuropsychiatric conditions, 1-SORAs do not have the strong sleep-promoting effect that DORAs do, thus giving 1-SORAs a distinct advantage as potential addiction and anxiety therapeutics. Two 1-SORAs, ACT-539313 and JNJ-61393215, are in clinical testing [54, 55].

\section{HCRTR2/OX 2 R}

\section{Putative Role in Sleep/Wake}

As mentioned above, HCRTR2/OX ${ }_{2} \mathrm{R}$ has an equal affinity for both HCRT1/orexin-A and HCRT2/orexin-B [2]. HCRTR2/OX ${ }_{2} \mathrm{R}$ is expressed primarily in the cortical layer VI, the nucleus accumbens, raphe nuclei, septal nuclei, the subthalamic and paraventricular thalamic nuclei, the anterior pretectal nucleus, and many hypothalamic nuclei including the tuberomammillary nucleus, dorsomedial nucleus, paraventricular nucleus, and premammillary nucleus (Fig. 1) [9]. Landmark studies have demonstrated that loss of orexin neurons and the resulting hypocretin/orexin deficiency is associated with narcolepsy type 1 (NT1) $[5,6,56]$. Mice lacking HCRTR2/OX 2 R exhibit a narcoleptic phenotype characterized by fragmentation of sleep-wake states and cataplexy-like episodes [39], while HCRTR1/ $O X_{1} R \mathrm{KO}$ mice only display mild fragmentation of sleep-wake cycles, with no other overt signs of narcoleptic symptomatology [41]. In the 1970s, several strains of large breed dogs were found to display an inherited narcolepsy-like phenotype characterized by cataplectic attacks, sleep fragmentation, and other sleep-wake symptoms associated with narcolepsy. This phenotype was transmitted as an autosomal recessive gene called canarc-1 that was later determined to encode a mutation in $\mathrm{HCRTR} 2 / \mathrm{OX}_{2} \mathrm{R}$ [4]. Together, these studies suggested a pivotal role for HCRTR2/OX $\mathrm{O}_{2} \mathrm{R}$ in the pathophysiology of narcolepsy, at least in animal models. The implication of the loss of hypocretin/orexin-containing neurons in the etiology of the human narcolepsy further suggested a sleep-wake regulatory function for this system. While HCRTR1/OX $\mathrm{O}^{\mathrm{R}}$ expression appears to be reduced in the brain of human narcoleptics, HCRTR2/OX $\mathrm{O}_{2}$ expression remains high [57]. Thus, the pharmacological substrate for a hypocretin/orexin therapeutic remains intact, a conclusion supported by studies demonstrating the amelioration of sleep symptoms in NT1 patients through the intranasal application of HCRT1/orexin-A $[43,44]$. Consequently, HCRTR2/OX $\mathrm{O}_{2}$ agonism could be an effective therapeutic strategy to address hypocretin/orexin deficiency in NT1, although it is also possible that combined HCRTR2/OX ${ }_{2} \mathrm{R}$ and HCRTR1/OX $\mathrm{O}_{1}$ agonism or $\mathrm{OX}_{1} \mathrm{R}$ agonism alone might bring some benefit to narcoleptics.

\section{Selective HCRTR2/OX ${ }_{2} \mathrm{R}$ Agonists}

Intrathecal and ICV administration of HCRT1/orexin-A increases wake and suppresses cataplexy in hypocretin/orexin neuron-ablated and hypocretin/orexin peptide-deficient mouse models of narcolepsy $[58,59]$ but not in HCRTR2/OX 2 R-deficient narcoleptic ca- 
nines [60], suggesting the potential for selective HCRTR2/OX ${ }_{2} \mathrm{R}$ agonists in the treatment of narcolepsy and other disorders of excessive sleepiness. The first selective nonpeptide HCRTR2/OX ${ }_{2} \mathrm{R}$ agonist, YNT185 $\left(\mathrm{EC}_{50}\right.$ on $\mathrm{OX}_{2} \mathrm{R}=23 \mathrm{nM}, \mathrm{OX}_{1} \mathrm{R} / \mathrm{OX}_{2} \mathrm{R} \mathrm{EC}_{50}$ ratio $\left.=70\right)$, was described in 2015 [61]. Systemic administration of YNT185 reduced cataplectic attacks in hypocretin/orexin peptide-deficient and hypocretin/orexin neuron-ablated mice but not in hypocretin/orexin receptor-deficient mice (Table 1) [62]. These results provided a proof-of-concept for hypocretin/orexin replacement therapy with HCRTR2/ $\mathrm{OX}_{2} \mathrm{R}$ agonists for NT1. Peripherally administered YNT185 promoted wakefulness in hypocretin/orexin-deficient, hypocretin/orexin neuron-ablated and wild-type mice, suggesting that hypocretin/orexin receptor agonists may be useful for treating sleepiness due to NT1 and other causes. No rebound was observed in sleep parameters during the active phase after YNT185-induced increases in wakefulness in either wild-type or hypocretin/ orexin-deficient mice; a result that should be more thoroughly investigated [62]. Ultimately though, YNT185 has limited in vivo efficacy and thus appears unsuitable for further clinical development.

Yukitake et al. [63] described the HCRTR2/OX ${ }_{2} \mathrm{R}$-selective agonist TAK925 (Table 1) with an $\mathrm{EC}_{50}$ on $\mathrm{OX}_{2} \mathrm{R}=5.5 \mathrm{nM}$ and $>5,000$-fold selectivity over HCRTR1/OX $\mathrm{R}$. TAK925 has modest wake-promoting effects in wild-type mice and nonhuman primates when injected subcutaneously or intravenously (Table 1) [64]. In the orexin/ataxin-3 mouse model of narcolepsy, TAK925 increased wake and reduced sleep-wake fragmentation and cataplexy (Table 1) [65]. The wake-promoting effect of TAK925 was not diminished after 14 days subchronic administration [65]. Preliminary data also showed that TAK925 attenuated body weight gain [66], a symptom in human narcolepsy that also occurs in orexin/ ataxin-3 mice without increases in daily food intake [67]. A Phase 1 study in healthy sleepdeprived adults demonstrated that TAK925 was well-tolerated and increased wakefulness at night compared to placebo [68]. If these results are confirmed in a broader Phase 2 study and the drug is found to be safe and effective, TAK925 could become the first narcoleptic therapeutic directed toward the neurotransmitter system whose dysfunction is implicated in the etiology of the disorder. However, TAK925 requires intravenous administration, which has driven The Takeda Pharmaceutical Company to pursue development of other orally available agonists more suitable for clinical application.

Ishikawa et al. [69] also described an orally available HCRTR2/OX ${ }_{2} \mathrm{R}$ agonist, TAK994 (Table 1), with an $\mathrm{EC}_{50}$ on $\mathrm{OX}_{2} \mathrm{R}=19 \mathrm{nM}$ and $>700$-fold selectivity against $\mathrm{OX}_{1} \mathrm{R}$. Oral administration of TAK994 during the sleep phase at $5 \mathrm{~h}$ into the light period promoted wakefulness in wild-type mice, but not in $H C R T R 2 / \mathrm{OX}_{2} R \mathrm{KO}$ mice (Table 1) [69]. Oral administration of TAK994 during the active phase in both orexin/ataxin-3 [67] and orexin-tTA;TetO DTA [70] narcolepsy mouse models significantly increased time spent in wake and improved wake maintenance while suppressing cataplectic episodes [71]. TAK994 had wake-promoting effects following chronic dosing for up to 14 days in orexin/ ataxin-3 mice without causing a sleep rebound [72]. A Phase 1 trial of TAK994 in healthy volunteers has been completed. 
Selective HCRTR2/OX 2 R Antagonists (2-SORAs)

Seltorexant (JNJ-42847922; MIN-202) is an orally active, high affinity, and selective HCRTR2/OX ${ }_{2} \mathrm{R}$ antagonist under development for the treatment of patients with major depressive disorder (MDD) and insomnia. Seltorexant crosses the blood-brain barrier and quickly occupies HCRTR2/OX $\mathrm{OX}_{2} \mathrm{R}$ binding sites in the rat brain [73]. In a randomized Phase 2 study to evaluate the efficacy of seltorexant in treating insomnia without psychiatric comorbidity [25], oral administration of seltorexant facilitated sleep onset and prolonged sleep duration while also improving sleep quality, as indicated by decreased WASO over the first $6 \mathrm{~h}$ of the night (Table 2). The improvement of these sleep parameters by seltorexant was significantly greater than zolpidem in this study [25]. Several other 2-SORAs have also shown promising sleep-promoting effects in preclinical testing (Table 1) $[48,74,75]$.

Insomnia is common in patients with MDD; however, the sleep-promoting effects of 2-SORAs have not been consistent in studies of MDD patients exhibiting insomnia. A Phase $2 \mathrm{~b}$ trial of seltorexant as adjunct to antidepressant therapy in adults with treatmentresistant MDD showed a statistically significant, dose-dependent decrease in LPS, increased TST, increased sleep efficiency, and a tendency towards subjectively improved mood (Table 2) [76, 77]. In a separate Phase 2 trial of seltorexant in MDD patients with insomnia [77], a decrease in LPS and WASO, and an increase in TST failed to reach significance. However, antidepressant efficacy was correlated significantly with increased delta-power during stage 2 sleep. Hypocretin/orexin neurons project to multiple brain regions involved in the secretion and regulation of stress hormones such as those involved in the hypothalamic-pituitary-adrenal (HPA) axis in animals (Fig. 1) (e.g., adrenocorticotropic hormone and cortisol) [78]. The HPA axis is known to be overactive in depressed patients, a significant proportion of whom suffer from insomnia. Use of 2-SORAs or DORAs for the treatment of insomnia in patients with MDD may also help stabilize the HPA axis, but both this potential action on the HPA axis and the efficacy of hypocretin/orexin antagonists for the treatment of nocturnal hyperarousal in MDD patients requires further exploration.

\section{Conclusions and Perspective}

Therapeutics targeting the hypocretin/orexin receptors for the treatment of addiction, anxiety, mood, and sleep disorders represent a relatively new principle, with just two hypocretin/orexin antagonists approved by mid-2021 by the FDA for use in humans for the treatment of insomnia. Given the range of physiological processes in which the hypocretin/orexin system has been implicated, hypocretin/orexin receptor antagonists/agonists have broad therapeutic potential. Several HCRTR2/OX ${ }_{2} \mathrm{R}$ agonists (Table 1), most notably TAK925 and more recently TAK994, have shown promise in both preclinical and clinical studies assessing their potential as treatments for narcolepsy with hypocretin/ orexin-deficiency. Both DORAs and 2-SORAs have been explored primarily for their 
sleep-promoting properties in humans, and DORAs along with 1-SORAs have shown promise in the reduction of reward in food and drug addiction paradigms in rodents (Tables 1 and 2). Polysomnographic (PSG) studies have revealed improved sleep quality and increased duration for both DORAs and 2-SORAs (Table 2) [15, 79, 80]. The clinical efficacy and safety profile of the DORA lemborexant is broadly similar to suvorexant, although the half-life of suvorexant is shorter. Lemborexant improves objective (PSG) and subjective measures of sleep onset and sleep maintenance compared with placebo (Table 2 ), with the most commonly reported adverse event being next-day somnolence [23]. There was no evidence of significant rebound insomnia or withdrawal effects following treatment discontinuation. To our knowledge, suvorexant and lemborexant have not been directly compared in humans. Several other hypocretin/orexin receptor antagonists including the 2-SORA seltorexant [25] are in clinical development and a New Drug Application for the DORA daridorexant was submitted in January 2021 (Table 2) [27]. DORAs have also shown promise in the treatment of nocturnal hyperarousal associated with other disorders, including insomnia that occurs during the clinical phase of Alzheimer's disease [81].

While the sleep-promoting effect of these compounds is well established (Tables 1 and 2 ), their influence on sleep architecture is somewhat controversial, with conflicting data on how DORAs modulate specific sleep states $[15,80,82,83]$. While it is well established that DORAs increase TST, several studies have found that this effect occurs primarily through an increase in REM sleep without a proportional increase in time spent in NREM sleep. By contrast, most studies utilizing 2-SORAs report that these compounds proportionally increase REM sleep and NREM sleep (Tables 1 and 2) [80]. Since coadministration of an $\mathrm{HCRTR} 1 / \mathrm{OX}_{1} \mathrm{R}$ antagonist with an $\mathrm{HCRTR} 2 / \mathrm{OX}_{2} \mathrm{R}$ antagonist has been shown to greatly attenuate the sleep-promoting effects of the HCRTR2/OX $\mathrm{O}_{2} \mathrm{R}$ antagonist, simultaneous inhibition of $\mathrm{HCRTR} 1 / \mathrm{OX}_{1} \mathrm{R}$ may reduce the sleep-promoting effects mediated by selective HCRTR2/OX ${ }_{2} \mathrm{R}$ antagonism [74]; however, this is contradicted by preclinical research showing that the 2-SORA MK-1064 requires higher receptor occupancy than a DORA to achieve the same sleep-promoting effect [84].

If subsequent research supports these observations of differential effects of 2-SORAs and DORAs on sleep substates, the clinical utility of these compounds may ultimately depend on the sleep phenotype of the target population. While there is a clear advantage in increasing TST when treating insomnia, the impact of potentially increasing REM sleep without proportionally increasing NREM sleep, which is generally regarded as the more restorative sleep state, is unclear and warrants further exploration. On the other hand, this feature of DORAs could also be exploited and may ultimately prove advantageous for the treatment of disorders associated with REM sleep deficiencies such as post-traumatic stress and anxiety disorders. Currently, information regarding the effect of DORAs and 2-SORAs on human sleep architecture is very limited; thus, conclusions based on the results reported to date should be considered preliminary. Ultimately, a systematic comparison of hypocretin/orexin antagonists on the NREM/REM ratio and TST in both pathological and healthy populations is needed to more clearly establish how these compounds 
affect sleep architecture. If the reported trend for 2-SORAs to proportionally increase both REM and NREM sleep is replicated in future studies and broader clinical trials, such compounds may prove to be very advantageous in the treatment of sleep disorders such as insomnia in which the sleep disruption is not specific to a particular sleep stage $[54,85]$.

\section{Key Take-Home Points}

- Although the hypocretin/orexin system has been implicated in numerous physiological processes, it is most prominently associated with its role in the regulation of arousal states.

- While HCRTR1/OX $\mathrm{O}$ has been implicated in the regulation of reward, motivation, and autonomic processes, HCRTR2/OX ${ }_{2} \mathrm{R}$ is most strongly associated with sleep-wake control.

- HCRTR2/OX ${ }_{2} \mathrm{R}$ activation promotes wakefulness whereas HCRTR2/OX ${ }_{2} \mathrm{R}$ antagonism promotes sleep.

- The regulatory role of the hypocretin/orexin system has made HCRTR1/OX $\mathrm{O}_{1}$ and HCRTR2/ $\mathrm{OX}_{2} \mathrm{R}$ attractive therapeutic targets and, as of mid-2021, two dual orexin receptor antagonists (DORAs) have been approved for treatment of disrupted nocturnal sleep.

- Selective HCRTR1/OX $\mathrm{O}_{1}$ and HCRTR2/OX $\mathrm{OX}_{2} \mathrm{R}$ antagonists (1- and 2-SORAs) have shown potential in preclinical testing for the treatment of drug and food reward, motivation, anxiety, and insomnia.

- Hypocretin/orexin deficiency due to degeneration of the hypocretin/orexin-producing neurons underlies the sleep disorder narcolepsy and hypocretin/orexin replacement therapy through development of small molecule agonists is an active area of research in the treatment of this disorder.

\section{Conflict of Interest Statement}

T.S.K. received consultancy fees from Idorsia Pharmaceuticals Ltd. during the development of this book, has been a Consultant for SK Life Sciences, Alkermes Pharmaceuticals, and Vida Ventures and has received research funds from Alkermes and Supernus Pharmaceuticals. The authors have no other conflicts of interest to declare.

\section{Funding Sources}

This work was supported by NIH R01 NS098813 and NIH R21 NS106882 to T.S.K. The content is solely the responsibility of the authors and does not necessarily represent the official views of the National Institutes of Health.

\section{Author Contributions}

All authors were involved in the development and review of the chapter, approved the final version to be published and take responsibility for all aspects of the work. 


\section{References}

1 de Lecea L, Kilduff TS, Peyron C, Gao X-B, Foye PE, Danielson PE, et al: The hypocretins: hypothalamusspecific peptides with neuroexcitatory activity. Proc Natl Acad Sci USA 1998;95:322-327.

2 Sakurai T, Amemiya A, Ishii M, Matsuzaki I, Chemelli $\mathrm{RM}$, Tanaka $\mathrm{H}$, et al: Orexins and orexin receptors: a family of hypothalamic neuropeptides and $\mathrm{G}$ proteincoupled receptors that regulate feeding behavior. Cell 1998;92:573-585.

3 Chemelli RM, Willie JT, Sinton CM, Elmquist JK, Scammell T, Lee C, et al: Narcolepsy in orexin knockout mice: molecular genetics of sleep regulation. Cell 1999;98: 437-451.

4 Lin L, Faraco J, Li R, Kadotani H, Rogers W, Lin X, et al: The sleep disorder canine narcolepsy is caused by a mutation in the hypocretin (orexin) receptor 2 gene. Cell 1999;98:365-376.

5 Thannickal T, Moore RY, Nienhuis R, Ramanathan L, Gulyani S, Aldrich M, et al: Reduced number of hypocretin neurons in human narcolepsy. Neuron 2000;27: 469-474.

6 Peyron C, Faraco J, Rogers W, Ripley B, Overeem S, Charnay Y, et al: A mutation in a case of early onset narcolepsy and a generalized absence of hypocretin peptides in human narcoleptic brains. Nat Med 2000;6: 991-997.

7 Kilduff TS, Peyron C: The hypocretin/orexin ligand-receptor system: implications for sleep and sleep disorders. Trends Neurosci 2000;23:359-365.

8 Beuckmann CT, Yanagisawa M: Orexins: from neuropeptides to energy homeostasis and sleep/wake regulation. J Mol Med (Berl) 2002;80:329-342.

9 Marcus JN, Aschkenasi CJ, Lee CE, Chemelli RM, Saper $\mathrm{CB}$, Yanagisawa M, et al: Differential expression of orexin receptors 1 and 2 in the rat brain. J Comp Neurol 2001;435:6-25.

10 Putula J, Kukkonen JP: Mapping of the binding sites for the OX1 orexin receptor antagonist, SB-334867, using orexin/hypocretin receptor chimaeras. Neurosci Lett 2012;506:111-115.

11 Yin J, Rosenbaum DM: The human orexin/hypocretin receptor crystal structures. Curr Top Behav Neurosci 2017;33:1-15.

12 Soya S, Sakurai T: Evolution of orexin neuropeptide system: structure and function. Front Neurosci 2020;14: 691.

13 Wang P, Wang M, Zhang L, Zhong S, Jiang W, Wang Z, et al: Functional characterization of an orexin neuropeptide in amphioxus reveals an ancient origin of orexin/orexin receptor system in chordate. Sci China Life Sci 2019;62:1655-1669.

14 Peyron C, Tighe DK, van den Pol AN, de Lecea L, Heller $\mathrm{HC}$, Sutcliffe JG, et al: Neurons containing hypocretin (orexin) project to multiple neuronal systems. J Neurosci 1998;18:9996-10015.

15 Brisbare-Roch C, Dingemanse J, Koberstein R, Hoever $\mathrm{P}$, Aissaoui H, Flores S, et al: Promotion of sleep by targeting the orexin system in rats, dogs and humans. Nat Med 2007;13:150-155.
16 Hoever P, de Haas SL, Dorffner G, Chiossi E, van Gerven JM, Dingemanse J: Orexin receptor antagonism: an ascending multiple-dose study with almorexant. J Psychopharmacol 2012;26:1071-1080.

17 Winrow CJ, Renger JJ: Discovery and development of orexin receptor antagonists as therapeutics for insomnia. Br J Pharmacol 2014;171:283-293.

18 Yin J, Mobarec JC, Kolb P, Rosenbaum DM: Crystal structure of the human OX2 orexin receptor bound to the insomnia drug suvorexant. Nature 2015;519:247250.

19 Etori K, Saito YC, Tsujino N, Sakurai T: Effects of a newly developed potent orexin-2 receptor-selective antagonist, compound $1 \mathrm{~m}$, on sleep/wakefulness states in mice. Front Neurosci 2014;8:8.

20 Winrow CJ, Gotter AL, Cox CD, Doran SM, Tannenbaum PL, Breslin MJ, et al: Promotion of sleep by suvorexant-a novel dual orexin receptor antagonist. J Neurogenet 2011;25:52-61.

21 Sun H, Kennedy WP, Wilbraham D, Lewis N, Calder N, Li X, et al: Effects of suvorexant, an orexin receptor antagonist, on sleep parameters as measured by polysomnography in healthy men. Sleep 2013;36(2):259-267.

22 Herring WJ, Connor KM, Snyder E, Snavely DB, Morin $\mathrm{CM}$, Lines $\mathrm{C}$, et al: Effects of suvorexant on the Insomnia Severity Index in patients with insomnia: analysis of pooled phase 3 data. Sleep Med 2019;56:219-223.

23 Murphy P, Moline M, Mayleben D, Rosenberg R, Zammit G, Pinner K, et al: Lemborexant, a dual orexin receptor antagonist (DORA) for the treatment of insomnia disorder: results from a Bayesian, adaptive, randomized, double-blind, placebo-controlled study. J Clin Sleep Med 2017;13:1289-1299.

24 Rosenberg R, Murphy P, Zammit G, Mayleben D, Kumar D, Dhadda S, et al: Comparison of lemborexant with placebo and zolpidem tartrate extended release for the treatment of older adults with insomnia disorder: a phase 3 randomized clinical trial. JAMA Netw Open 2019;2:e1918254.

25 De Boer P, Drevets WC, Rofael H, van der Ark P, Kent JM, Kezic I, et al: A randomized Phase 2 study to evaluate the orexin-2 receptor antagonist seltorexant in individuals with insomnia without psychiatric comorbidity. J Psychopharmacol 2018;32:668-677.

26 Letavic MA, Bonaventure P, Carruthers NI, Dugovic C, Koudriakova T, Lord B, et al: Novel octahydropyrrolo[3, 4-c]pyrroles are selective orexin-2 antagonists: SAR leading to a clinical candidate. J Med Chem 2015;58: 5620-5636.

27 Dauvilliers Y, Zammit G, Fietze I, Mayleben D, Seboek Kinter D, Pain S, et al: Daridorexant, a new dual orexin receptor antagonist to treat insomnia disorder. Ann Neurol 2020;87:347-356.

28 Zammit G, Dauvilliers Y, Pain S, Sebok Kinter D, Mansour Y, Kunz D. Daridorexant, a new dual orexin receptor antagonist, in elderly subjects with insomnia disorder. Neurology 2020;94:e2222-e32. 
29 Treiber A, de Kanter R, Roch C, Gatfield J, Boss C, von Raumer M, et al: The use of physiology-based pharmacokinetic and pharmacodynamic modeling in the discovery of the dual orexin receptor antagonist ACT541468. J Pharmacol Exp Ther 2017;362:489-503.

30 Winrow CJ, Gotter AL, Cox CD, Tannenbaum PL, Garson SL, Doran SM, et al: Pharmacological characterization of MK-6096 - a dual orexin receptor antagonist for insomnia. Neuropharmacology 2012;62:978-987.

31 Connor KM, Mahoney E, Jackson S, Hutzelmann J, Zhao $\mathrm{X}$, Jia N, et al: A phase II dose-ranging study evaluating the efficacy and safety of the orexin receptor antagonist filorexant (MK-6096) in patients with primary insomnia. Int J Neuropsychopharmacol 2016;19.

32 Abbas MG, Shoji H, Soya S, Hondo M, Miyakawa T, Sakurai T: Comprehensive behavioral analysis of male Oxlr (-/-) mice showed implication of orexin receptor-1 in mood, anxiety, and social behavior. Front Behav Neurosci 2015;9:324.

33 Mahler SV, Moorman DE, Smith RJ, James MH, AstonJones G: Motivational activation: a unifying hypothesis of orexin/hypocretin function. Nat Neurosci 2014;17: 1298-1303.

34 Nair SG, Golden SA, Shaham Y: Differential effects of the hypocretin 1 receptor antagonist SB 334867 on highfat food self-administration and reinstatement of food seeking in rats. Br J Pharmacol 2008;154:406-416.

35 Smart D, Sabido-David C, Brough SJ, Jewitt F, Johns A, Porter RA, et al: SB-334867-A: the first selective orexin-1 receptor antagonist. Br J Pharmacol 2001;132: $1179-1182$.

36 Aston-Jones G, Smith RJ, Sartor GC, Moorman DE, Massi L, Tahsili-Fahadan P, et al: Lateral hypothalamic orexin/hypocretin neurons: a role in reward-seeking and addiction. Brain Res 2010;1314:74-90.

37 Jupp B, Krivdic B, Krstew E, Lawrence AJ: The orexin(1) receptor antagonist SB-334867 dissociates the motivational properties of alcohol and sucrose in rats. Brain Res 2011;1391:54-59.

38 Bonaventure P, Dugovic C, Shireman B, Preville C, Yun S, Lord B, et al: Evaluation of JNJ-54717793 a novel brain penetrant selective orexin 1 receptor antagonist in two rat models of panic attack provocation. Front Pharmacol 2017;8:357.

39 Willie JT, Chemelli RM, Sinton CM, Tokita S, Williams SC, Kisanuki YY, et al: Distinct narcolepsy syndromes in orexin receptor-2 and orexin null mice: molecular genetic dissection of non-REM and REM sleep regulatory processes. Neuron 2003;38:715-730.

40 Kalogiannis M, Hsu E, Willie JT, Chemelli RM, Kisanuki YY, Yanagisawa M, et al. Cholinergic modulation of narcoleptic attacks in double orexin receptor knockout mice. PLoS One 2011;6:e18697.

41 Tsujino N, Sakurai T. Orexin/hypocretin: a neuropeptide at the interface of sleep, energy homeostasis, and reward system. Pharmacol Rev 2009;61:162-176.

42 Mieda M, Hasegawa E, Kisanuki YY, Sinton CM, Yanagisawa $M$, Sakurai T: Differential roles of orexin receptor- 1 and -2 in the regulation of non-REM and REM sleep. J Neurosci 2011;31:6518-6526.
43 Baier PC, Hallschmid M, Seeck-Hirschner M, Weinhold SL, Burkert S, Diessner N, et al: Effects of intranasal hypocretin-1 (orexin A) on sleep in narcolepsy with cataplexy. Sleep Med 2011;12:941-946.

44 Weinhold SL, Seeck-Hirschner M, Nowak A, Hallschmid M, Goder R, Baier PC: The effect of intranasal orexin-A (hypocretin-1) on sleep, wakefulness and attention in narcolepsy with cataplexy. Behav Brain Res 2014;262: 8-13.

45 Boutrel B, Kenny PJ, Specio SE, Martin-Fardon R, Markou A, Koob GF, et al: Role for hypocretin in mediating stress-induced reinstatement of cocaine-seeking behavior. Proc Natl Acad Sci USA 2005;102:19168-19173.

46 Ito N, Yabe T, Gamo Y, Nagai T, Oikawa T, Yamada H, et al: I.c.v. administration of orexin-A induces an antidepressive-like effect through hippocampal cell proliferation. Neuroscience 2008;157:720-732.

47 Takahashi N, Okumura T, Yamada H, Kohgo Y: Stimulation of gastric acid secretion by centrally administered orexin-A in conscious rats. Biochem Biophys Res Commun 1999;254:623-627.

48 Morairty SR, Revel FG, Malherbe P, Moreau JL, Valladao D, Wettstein JG, et al: Dual hypocretin receptor antagonism is more effective for sleep promotion than antagonism of either receptor alone. PLoS One 2012; 7:e39131.

49 Smith MI, Piper DC, Duxon MS, Upton N: Evidence implicating a role for orexin-1 receptor modulation of paradoxical sleep in the rat. Neurosci Lett 2003;341: 256-258.

50 Steiner MA, Gatfield J, Brisbare-Roch C, Dietrich H, Treiber A, Jenck F, et al: Discovery and characterization of ACT-335827, an orally available, brain penetrant orexin receptor type 1 selective antagonist. Chem Med Chem 2013;8:898-903.

51 Stump CA, Cooke AJ, Bruno J, Cabalu TD, Gotter AL, Harell CM, et al: Discovery of highly potent and selective orexin 1 receptor antagonists (1-SORAs) suitable for in vivo interrogation of orexin 1 receptor pharmacology. Bioorg Med Chem Lett 2016;26:5809-5814.

52 Futamura A, Nozawa D, Araki Y, Tamura Y, Tokura S, Kawamoto H, et al: Identification of highly selective and potent orexin receptor 1 antagonists derived from a dual orexin receptor $1 / 2$ antagonist based on the structural framework of pyrazoylethylbenzamide. Bioorg Med Chem 2017;25:5203-5215.

53 Hellmann J, Drabek M, Yin J, Gunera J, Pröll T, Kraus F, et al: Structure-based development of a subtype-selective orexin 1 receptor antagonist. Proc Natl Acad Sci USA 2020;117:18059-18067.

54 Kaufmann P, Ort M, Golor G, Kornberger R, Dingemanse J: First-in-human study with ACT-539313, a novel selective orexin-1 receptor antagonist. Br J Clin Pharmacol 2020;86:1377-1386.

55 Salvadore G, Bonaventure P, Shekhar A, Johnson PL, Lord B, Shireman BT, et al: Translational evaluation of novel selective orexin-1 receptor antagonist JNJ61393215 in an experimental model for panic in rodents and humans. Transl Psychiatry 2020;10:308. 
56 Nishino S, Ripley B, Overeem S, Lammers GJ, Mignot E: Hypocretin (orexin) deficiency in human narcolepsy. Lancet 2000;355:39-40.

57 Mishima K, Fujiki N, Yoshida Y, Sakurai T, Honda M, Mignot E, et al: Hypocretin receptor expression in canine and murine narcolepsy models and in hypocretinligand deficient human narcolepsy. Sleep 2008;31:11191126.

58 Kaushik MK, Aritake K, Imanishi A, Kanbayashi T, Ichikawa T, Shimizu T, et al: Continuous intrathecal orexin delivery inhibits cataplexy in a murine model of narcolepsy. Proc Natl Acad Sci USA 2018;115:60466051.

59 Mieda M, Willie JT, Hara J, Sinton CM, Sakurai T, Yanagisawa M: Orexin peptides prevent cataplexy and improve wakefulness in an orexin neuron-ablated model of narcolepsy in mice. Proc Natl Acad Sci USA 2004; 101:4649-4654.

60 Fujiki N, Yoshida Y, Ripley B, Mignot E, Nishino S: Effects of IV and ICV hypocretin-1 (orexin A) in hypocretin receptor-2 gene mutated narcoleptic dogs and IV hypocretin-1 replacement therapy in a hypocretin-ligand-deficient narcoleptic dog. Sleep 2003;26:953-959.

61 Nagahara T, Saitoh T, Kutsumura N, Irukayama-Tomobe Y, Ogawa Y, Kuroda D, et al: Design and synthesis of non-peptide, selective orexin receptor 2 agonists. J Med Chem 2015;58:7931-7937.

62 Irukayama-Tomobe $Y$, Ogawa $Y$, Tominaga H, Ishikawa Y, Hosokawa N, Ambai S, et al: Nonpeptide orexin type2 receptor agonist ameliorates narcolepsy-cataplexy symptoms in mouse models. Proc Natl Acad Sci USA 2017;114:5731-5736.

63 Yukitake H, Fujimoto T, Ishikawa T, Suzuki A, Shimizu Y, Rikimaru K, et al: TAK-925, an orexin 2 receptor-selective agonist, shows robust wake-promoting effects in mice. Pharmacol Biochem Behav 2019;187:172794.

64 Yukitake H, Ishikawa T, Suzuki A: An orexin 2 receptorselective agonist, TAK-925, shows robust wake-promoting effects in mice and non-human primates. Sleep 2018;41:A1.

65 Suzuki M, Yukitake H, Ishikawa T, Kimura H: An orexin 2 receptor-selective agonist TAK-925 ameliorates narcolepsy-like symptoms in orexin/ataxin-3 mice. Sleep 2018;41:A1.

66 Kimura H, Ishikawa T, Yukitake H, Suzuki M: An orexin 2 receptor-selective agonist, TAK-925, ameliorates narcolepsy-like symptoms and obesity in orexin/ataxin-3 transgenic mice. Sleep 2019;42:A23.

67 Hara J, Beuckmann CT, Nambu T, Willie JT, Chemelli RM, Sinton CM, et al: Genetic ablation of orexin neurons in mice results in narcolepsy, hypophagia, and obesity. Neuron 2001;30:345-354.

68 Evans R, Hazel J, Faessel H, Wu J, Hang Y, Alexande R, et al: Results of a phase 1, 4-period crossover, placebocontrolled, randomized, single dose study to evaluate the safety, tolerability, pharmacokinetics, and pharmacodynamics of TAK-925, a novel orexin 2 receptor agonist, in sleep-deprived, healthy adults, utilizing modafinil as an active comparator. Sleep Med 2019; 64:S106.
69 Ishikawa T, Suzuki M, Kajita Y, Miyanohana Y, Koike T, Kimura H: Discovery of a novel, orally available orexin 2 receptor-selective agonist, TAK-994, as a therapeutic drug for narcolepsy. Sleep Med 2019;64:S170.

70 Tabuchi S, Tsunematsu T, Black SW, Tominaga M, Maruyama M, Takagi K, et al: Conditional ablation of orexin/hypocretin neurons: a new mouse model for the study of narcolepsy and orexin system function. J Neurosci 2014;34:6495-6509.

71 Kimura H, Ishikawa T, Suzuki M: A novel, orally available orexin 2 receptor-selective agonist, TAK-994, ameliorates narcolepsy-like symptoms in narcolepsy mouse models. Sleep Med 2019;64:S199.

72 Ishikawa T, Suzuki M, Kimura H: A novel, orally available orexin 2 receptor-selective agonist, TAK-994, shows wake-promoting effects following chronic dosing in an orexin-deficient narcolepsy mouse model. Sleep 2020;43:A56.

73 Bonaventure P, Shelton J, Yun S, Nepomuceno D, Sutton S, Aluisio L, et al: Characterization of JNJ-42847922, a selective orexin-2 receptor antagonist, as a clinical candidate for the treatment of insomnia. J Pharmacol Exp Ther 2015;354:471-482.

74 Dugovic C, Shelton JE, Aluisio LE, Fraser IC, Jiang X, Sutton SW, et al: Blockade of orexin-1 receptors attenuates orexin-2 receptor antagonism-induced sleep promotion in the rat. J Pharmacol Exp Ther 2009;330:142151.

75 Roecker AJ, Reger TS, Mattern MC, Mercer SP, Bergman JM, Schreier JD, et al: Discovery of MK-3697: a selective orexin 2 receptor antagonist (2-SORA) for the treatment of insomnia. Bioorg Med Chem Lett 2014;24: 4884-4890

76 Recourt K, de Boer P, Zuiker R, Luthringer R, Kent J, van der Ark P, et al: The selective orexin-2 antagonist seltorexant (JNJ-42847922/MIN-202) shows antidepressant and sleep-promoting effects in patients with major depressive disorder. Transl Psychiatry 2019;9:216.

77 Brooks S, Jacobs GE, de Boer P, Kent JM, Van Nueten L, van Amerongen $\mathrm{G}$, et al. The selective orexin-2 receptor antagonist seltorexant improves sleep: an exploratory double-blind, placebo controlled, crossover study in antidepressant-treated major depressive disorder patients with persistent insomnia. J Psychopharmacol 2019;33:202-209.

78 Spinazzi R, Andreis PG, Rossi GP, Nussdorfer GG: Orexins in the regulation of the hypothalamic-pituitary-adrenal axis. Pharmacol Rev. 2006;58:46-57.

79 Hoyer D, Jacobson LH: Orexin in sleep, addiction and more: is the perfect insomnia drug at hand? Neuropeptides 2013;47:477-488.

80 Jacobson LH, Chen S, Mir S, Hoyer D: Orexin OX2 receptor antagonists as sleep aids. Curr Top Behav Neurosci 2017;33:105-136.

81 Herring WJ, Ceesay P, Snyder E, Bliwise D, Budd K, Hutzelmann J, et al: Polysomnographic assessment of suvorexant in patients with probable Alzheimer's disease dementia and insomnia: a randomized trial. Alzheimers Dement 2020;16:541-551. 
82 Herring WJ, Roth T, Krystal AD, Michelson D: Orexin receptor antagonists for the treatment of insomnia and potential treatment of other neuropsychiatric indications. J Sleep Res 2019;28:e12782.

83 Sutton EL: Profile of suvorexant in the management of insomnia. Drug Des Devel Ther 2015;9:6035-6042.

84 Gotter AL, Forman MS, Harrell CM, Stevens J, Svetnik $\mathrm{V}$, Yee KL, et al: Orexin 2 receptor antagonism is sufficient to promote NREM and REM sleep from mouse to man. Sci Rep 2016;6:27147.

85 Clark JW, Brian ML, Drummond SPA, Hoyer D, Jacobson LH: Effects of orexin receptor antagonism on human sleep architecture: a systematic review. Sleep Med Rev 2020;53:101332.

86 Black SW, Morairty SR, Fisher SP, Chen TM, Warrier DR, Kilduff TS: Almorexant promotes sleep and exacerbates cataplexy in a murine model of narcolepsy. Sleep 2013;36:325-336.

87 Beuckmann CT, Ueno T, Nakagawa M, Suzuki M, Akasofu S: Preclinical in vivo characterization of lemborexant (E2006), a novel dual orexin receptor antagonist for sleep/wake regulation. Sleep 2019;42:zsz076.

88 Mahoney CE, Mochizuki T, Scammell TE: Dual orexin receptor antagonists increase sleep and cataplexy in wild type mice. Sleep 2020;43:zsz302.

89 Cox CD, Breslin MJ, Whitman DB, Schreier JD, McGaughey GB, Bogusky MJ, et al: Discovery of the dual orexin receptor antagonist [(7R)-4-(5-chloro-1, 3-benzoxazol-2-yl)-7-methyl-1, 4-diazepan-1-yl] [5-methy 1-2-(2H-1, 2, 3-triazol-2-yl)phenyl]methanone (MK4305) for the treatment of insomnia. J Med Chem 2010; 53:5320-5332.

90 Bonaventure P, Yun S, Johnson PL, Shekhar A, Fitz SD, Shireman BT, et al: A selective orexin-1 receptor antagonist attenuates stress-induced hyperarousal without hypnotic effects. J Pharmacol Exp Ther 2015;352:590601.

91 Gozzi A, Turrini G, Piccoli L, Massagrande M, Amantini $\mathrm{D}$, Antolini M, et al: Functional magnetic resonance imaging reveals different neural substrates for the effects of orexin- 1 and orexin-2 receptor antagonists. PLoS One 2011;6:e16406.

92 Kuduk SD, Skudlarek JW, DiMarco CN, Bruno JG, Pausch MH, O'Brien JA, et al: Identification of MK8133: an orexin-2 selective receptor antagonist with favorable development properties. Bioorg Med Chem Lett 2015;25:2488-2492.
93 Black J, Pillar G, Hedner J, Polo O, Berkani O, Mangialaio $\mathrm{S}$, et al: Efficacy and safety of almorexant in adult chronic insomnia: a randomized placebo-controlled trial with an active reference. Sleep Med 2017;36:8694.

94 Roth T, Black J, Cluydts R, Charef P, Cavallaro M, Kramer F, et al: Dual orexin receptor antagonist, almorexant, in elderly patients with primary insomnia: a randomized, controlled study. Sleep 2017;40:zsw034.

95 Bettica P, Nucci G, Pyke C, Squassante L, Zamuner S, Ratti E, et al: Phase I studies on the safety, tolerability, pharmacokinetics and pharmacodynamics of SB649868, a novel dual orexin receptor antagonist. J Psychopharmacol 2012;26:1058-1070.

96 Bettica P, Squassante L, Groeger JA, Gennery B, Winsky-Sommerer R, Dijk DJ: Differential effects of a dual orexin receptor antagonist (SB-649868) and zolpidem on sleep initiation and consolidation, SWS, REM sleep, and EEG power spectra in a model of situational insomnia. Neuropsychopharmacology 2012;37:12241233.

97 Bettica P, Squassante L, Zamuner S, Nucci G, DankerHopfe H, Ratti E: The orexin antagonist SB-649868 promotes and maintains sleep in men with primary insomnia. Sleep 2012;35:1097-1104.

98 Struyk A, Gargano C, Drexel M, Stoch SA, Svetnik V, $\mathrm{Ma}$ J, et al: Pharmacodynamic effects of suvorexant and zolpidem on EEG during sleep in healthy subjects. Eur Neuropsychopharmacol 2016;26:1649-1656.

99 Snyder E, Ma J, Svetnik V, Connor KM, Lines C, Michelson D, et al: Effects of suvorexant on sleep architecture and power spectral profile in patients with insomnia: analysis of pooled phase 3 data. Sleep Med 2016;19:93-100.

100 Sun H, Palcza J, Card D, Gipson A, Rosenberg R, Kryger M, et al: Effects of suvorexant, an orexin receptor antagonist, on respiration during sleep in patients with obstructive sleep apnea. J Clin Sleep Med 2016; 12:9-17.

101 Sun H, Palcza J, Rosenberg R, Kryger M, Siringhaus T, Rowe J, et al: Effects of suvorexant, an orexin receptor antagonist, on breathing during sleep in patients with chronic obstructive pulmonary disease. Respir Med 2015;109:416-426.

102 van der Ark PD, Golor G, van Nueten L, Nandy P, de Boer P: Multiple daytime administration of the selective orexin-2 receptor antagonist JNJ-42847922 induces somnolence in healthy subjects without residual central effects. J Psychopharmacol 2018;32:13301340 .
Thomas S. Kilduff

Center for Neuroscience, Biosciences Division, SRI International 333 Ravenswood Ave

Menlo Park, CA 94025 (USA)

thomas.kilduff@sri.com 